\title{
Mulch decomposition and nitrogen, phosphorus and potassium release in vetiver grass at different plant densities ${ }^{1}$
}

\author{
Jaídson Gonçalves da Rocha², Fábio Cunha Coelho ${ }^{2}$, Rosana Teixeira Lelis ${ }^{2}$, \\ Gabriela Carvalho de Souza Santos ${ }^{2}$, Mario Euclides Pechara da Costa Jaeggi ${ }^{2}$
}

\section{ABSTRACT}

In order to meet the need for nutrients or soil cover, when plants are used as green manure, it is necessary to determine the ideal plant population, as well as the amount and duration of released nutrients. This study aimed to assess the decomposition and nitrogen $(\mathrm{N})$, phosphorus $(\mathrm{P})$ and potassium $(\mathrm{K})$ release rates of vetiver grass mulch. A split-plot arrangement was used, with the plots consisting of mulch decomposition times after cutting $(0,15,25,70$ and 125 days) and the subplots of vetiver plant densities (1, 2, 3 and 4 plants $\mathrm{m}^{-2}$ ). A randomized block design was used, with four replications. The highest release rates for N, P and $\mathrm{K}$ were recorded during the first five days. The plant density of 3 plants $\mathrm{m}^{-2}$ exhibited the highest mulch dry weight at 125 days and contained more $\mathrm{N}, \mathrm{P}$ and $\mathrm{K}$, when compared to the populations of 1,2 and 4 plants $\mathrm{m}^{-2}$.

KEYWORDS: Chrysopogon zizanoides (L.) Robert, nutrient cycling, green manure.

\section{INTRODUCTION}

Vetiver grass [Chrysopogon zizaniodes (L.) Robert] is a perennial plant from the Poaceae family, whose morphological characteristics are very similar to those of aromatic plants such as lemongrass [Cymbopogon citratus (DC) Stapf.], citronella grass [Cymbopogon nardus (L.) Rendle] and palmarosa (Cymbopogon martinii var. Motia Bruno) (D’Souza et al. 2019). It is known as "the wonder grass", due to its wide variety of medicinal (fever, rheumatism, sexual diseases, burns, insect and snake bites, etc.), herbal (antiseptic, anti-inflammatory, antioxidant, etc.) and industrial (cosmetics, perfumes, fragrances, etc.) applications (Shabbir et al. 2019).

\section{RESUMO}

Decomposição de palhada e liberação de nitrogênio, fósforo e potássio em capim-vetiver com diferentes populações de plantas

A fim de atender a demanda de nutrientes ou cobertura do solo, quando se utilizam plantas para adubação verde, é necessário o conhecimento da adequada população de plantas, quantidade de nutrientes liberada e período de liberação. Objetivou-se verificar a taxa de decomposição e a liberação de nitrogênio $(\mathrm{N})$, fósforo $(\mathrm{P})$ e potássio $(\mathrm{K})$ da palhada de capim-vetiver. Utilizou-se arranjo de parcelas subdivididas, sendo as parcelas constituídas por períodos de decomposição da palhada após o corte $(0,15,25,70$ e 125 dias $)$ e as subparcelas por populações de capim-vetiver $\left(1,2,3\right.$ e 4 plantas $\left.\mathrm{m}^{-2}\right)$. O delineamento experimental foi em blocos casualizados, com quatro repetições. Para N, Pe K, as maiores liberações ocorreram durante os primeiros cinco dias. A população de 3 plantas $\mathrm{m}^{-2}$ foi a que apresentou a maior massa seca de palhada aos 125 dias, e a mesma continha mais $\mathrm{N}, \mathrm{P}$ e K, se comparada às populações de 1,2 e 4 plantas $\mathrm{m}^{-2}$.

PALAVRAS-CHAVE: Chrysopogon zizanoides (L.) Robert, ciclagem de nutrientes, adubação verde.

Its uses include heavy metal detoxification of soil and water, due to the absorption capacity of its roots (Banerjee et al. 2019). In addition to its substantial growth potential and adaptability to different environments, the vetiver grass exhibits a high biomass production (approximately $100 \mathrm{Mg}$ ha $^{-1}$ year ${ }^{-1}$ ) and can be grown in a wide range of soils (Antiochia et al. 2007, Danh et al. 2009), including saline, sodic, sandy and flooded soils (Lal 2013).

A plant suitability as green manure or soil cover depends on characteristics such as mulch production and soil coverage, nutrient availability and adaptation to the local climate and soil. Crusciol et al. (2008) observed that the soil cover is a source of nutrients for subsequent crops. This kind of

\footnotetext{
${ }^{1}$ Received: July 22, 2020. Accepted: Oct. 15, 2020. Published: Nov. 30, 2020. DOI: 10.1590/1983-40632020v5064603.

${ }^{2}$ Universidade Estadual do Norte Fluminense Darcy Ribeiro, Centro de Ciências e Tecnologias Agropecuárias, 
plant has an aggressive root system that absorbs nutrients in subsurface layers and subsequently releases them during decomposition (Carvalho et al. 2011). According to Linhares et al. (2009), a synergy between mineralization in plant residue decomposition and crop growth stage with the highest nutrient requirements is important for green manure to be more effective.

The term "decomposition" refers to breaking down an organic material into smaller constituent parts (Mason 1980). Kliemann et al. (2006) reported that knowing how plant residues decompose is important for understanding the nutrient cycling process. Decomposition plays a vital role in the nutrient distribution within agroecosystems, and the decomposition rate may be decisive in selecting a green manure or cover crop. As such, the increasing use of grasses as soil cover has proved effective, in terms of amount of biomass produced and maintaining adequate coverage (Assis et al. 2016). Concomitantly, knowing the decomposition rate of plant residues enables a better understanding of the biogeochemical cycles of agroecosystems (Gołębiewski et al. 2019), which may then be used to improve crop yield.

The ability of the vetiver shoot biomass to serve as soil cover and simultaneously supply mineral nutrients is related to the amount of biomass produced, its decomposition rate and the release of these nutrients into the soil or crop (Lakshmi \& Sekhar 2020).

Thus, this study aimed at assessing the decomposition rate and release of primary micronutrients of vetiver grass mulch grown at different plant densities, under an agroecological production system.

\section{MATERIAL AND METHODS}

The experiment was conducted in Campos dos Goytacazes, Rio de Janeiro state, Brazil ( $21^{\circ} 51^{\prime} \mathrm{S}, 41^{\circ} 16^{\prime} \mathrm{W}$ and altitude of $\left.14 \mathrm{~m}\right)$, from November 18, 2016 to April 5, 2018, in an area with $750 \mathrm{~m}^{2}$, where the soil is classified as Haplic Cambisol (Barros Junior 2011), with the following characteristics $(0-20 \mathrm{~cm}$ layer $): \mathrm{pH}=7.0 ; \mathrm{P}=$ $560 \mathrm{mg} \mathrm{dm}^{-3} ; \mathrm{K}=549 \mathrm{mg} \mathrm{dm}^{-3} ; \mathrm{Ca}=12.0 \mathrm{cmol}_{\mathrm{c}} \mathrm{dm}^{-3}$; $\mathrm{Mg}=2.2 \mathrm{cmol}_{\mathrm{c}} \mathrm{dm}^{-3} ; \mathrm{H}+\mathrm{Al}=1.3 \mathrm{cmol}_{\mathrm{c}} \mathrm{dm}^{-3}$; $\mathrm{Na}=2.8 \mathrm{cmol}_{\mathrm{c}} \mathrm{dm}^{-3} ; \mathrm{C}=2.8 \% ; \mathrm{OM}=48.4 \mathrm{~g} \mathrm{dm}^{3}$; $\mathrm{SB}=18.2 \mathrm{cmol}_{\mathrm{c}} \mathrm{dm}^{-3} ; \mathrm{T}=18.5 \mathrm{cmol}_{\mathrm{c}} \mathrm{dm}^{-3} ; \mathrm{t}=$ $18.4 \mathrm{cmol} \mathrm{dm}^{-3} ; \mathrm{V}=93.3 \% ; \mathrm{Fe}=29.7 \mathrm{mg} \mathrm{dm}^{-3}$; $\mathrm{Cu}=2.6 \mathrm{mg} \mathrm{dm}^{-3} ; \mathrm{Zn}=13.5 \mathrm{mg} \mathrm{dm}^{-3}$; and $\mathrm{Mn}=$ $61.1 \mathrm{mg} \mathrm{dm}^{-3}$.

The average monthly temperature and rainfall during the study period were registered at the Campos dos Goytacazes automatic weather station (Brasil 2018). The total rainfall throughout the experiment was $1,746.7 \mathrm{~mm}$, with average temperature and relative humidity of $25.6^{\circ} \mathrm{C}$ and $72.6 \%$, respectively (Figure 1).

A split-plot arrangement was used, with the plots consisting of vetiver mulch decomposition times after cutting $(0,15,25,70$ and 125 days) and the subplots of plant densities (1, 2, 3 and 4 plants $\mathrm{m}^{-2}$ ). A randomized block design was used, with four replications.

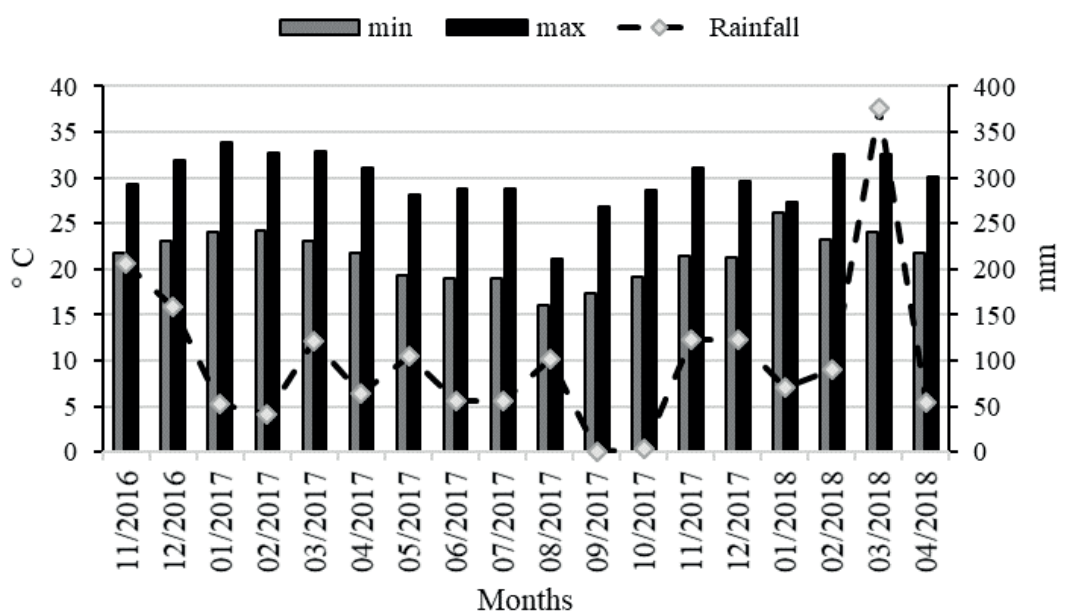

Figure 1. Maximum and minimum temperatures $\left({ }^{\circ} \mathrm{C}\right)$ and rainfall $(\mathrm{mm})$, in Campos dos Goytacazes, Rio de Janeiro state, Brazil, form November 2016 to April 2018. 
Each experimental unit contained three 5-m-long rows of vetiver grass, spaced $1 \mathrm{~m}$ apart, with a total area of $15 \mathrm{~m}^{2}$ for each experimental unit and the study area consisting of the center row $\left(5 \mathrm{~m}^{2}\right)$.

The vetiver grass was planted by vegetative propagation, using seedlings. The tillage in the planting area consisted of plowing and harrowing, and an organic fertilizer was applied using $1.35 \mathrm{Mg} \mathrm{ha}^{-1}$ of cow manure $(\mathrm{pH}=6.8 ; \mathrm{N}=$ $15 \mathrm{~g} \mathrm{~kg}^{-1} ; \mathrm{P}_{2} \mathrm{O}_{5}=11.62 \mathrm{~g} \mathrm{~kg}^{-1} ; \mathrm{K}_{2} \mathrm{O}=10.29 \mathrm{~g} \mathrm{~kg}^{-1}$; $\mathrm{Ca}=9.44 \mathrm{~g} \mathrm{~kg}^{-1} ; \mathrm{Mg}=5.62 \mathrm{~g} \mathrm{~kg}^{-1} ; \mathrm{C}=206.4 \mathrm{~g} \mathrm{~kg}^{-1}$; $\mathrm{RH}=32.11 \% ; \mathrm{Fe}=163.89 \mathrm{mg} \mathrm{kg}^{-1} ; \mathrm{Cu}=42 \mathrm{mg} \mathrm{kg}^{-1}$; $\left.\mathrm{Zn}=144 \mathrm{mg} \mathrm{kg}^{-1} ; \mathrm{Mn}=598 \mathrm{mg} \mathrm{kg}^{-1}\right)$. The area had remained predominantly fallow for approximately 10 years before the vetiver grass was planted.

Eleven months after planting, the shoots were cut at a height of about $10 \mathrm{~cm}$, using a rotary cutter, and weighed to obtain the fresh dry mass of each experimental unit, and then uniformly deposited on the soil in the respective experimental units.

The litter bag method was used to determine the decomposition rate of the vetiver grass mulch. The bags were made from $1.55 \mathrm{~mm}$ mesh nylon and measured 0.20 x $0.20 \mathrm{~m}$ (Thomas \& Asakawa 1993). They were filled with vetiver shoots, determined based on the proportion of total fresh mass for the study area of the plot $\left(5 \mathrm{~m}^{2}\right)$ and the total area of the bag $\left(0.04 \mathrm{~m}^{2}\right)$. Five bags per plot were placed along the center row of the experimental unit, together with the mulch (Figure 2). Next, the litter bags were collected at the five vetiver mulch decomposition times after cutting $(0,15,25,70$ and 125 days) (Figure 2).

The N, P and $\mathrm{K}$ contents of the vetiver mulch were determined using the dry matter of the vetiver

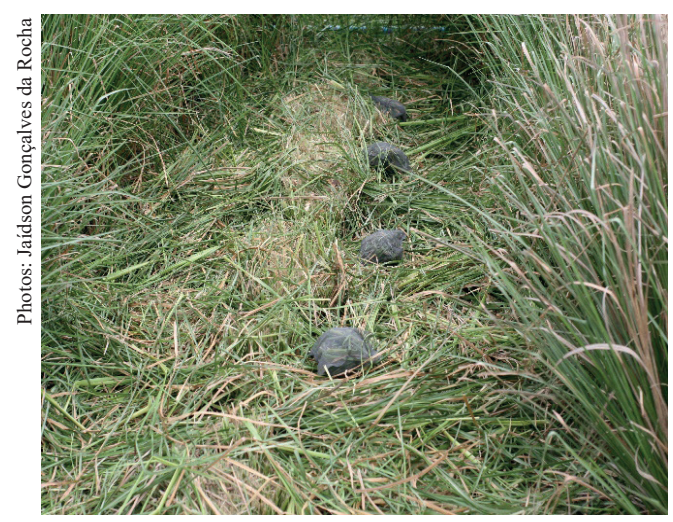

shoots in the litter bags as samples. To that end, the samples were removed from the bags at the different decomposition times and dried in a forced air oven at $70^{\circ} \mathrm{C}$, for 72 hours. Next, they were weighed, ground in a 20-mesh Wiley mill and stored in hermetically sealed flasks.

In order to determine the $\mathrm{N}, \mathrm{P}$ and $\mathrm{K}$ contents of the decomposing mulch, $0.1 \mathrm{~g}$ of the previously dried and ground samples was removed and submitted to sulfuric acid digestion. The $\mathrm{N}$ content was determined using the Nessler method (reagent A - Nessler's reagent/reagent B - sodium tartrate) (Jackson 1965) and $\mathrm{P}$ with reagent $\mathrm{A}$ (ammonium molybdate)/reagent $\mathrm{B}(0.8 \%$ vitamin $\mathrm{C})$, in a spectrophotometer (Specord 210, Analystik Jena). The K content was measured in a flame photometer.

The effects of the decomposition times and plant densities were assessed by analysis of variance (F-test) at 1 and $5 \%$ of probability. Regression analysis was performed in the event of a significant effect. All the statistical analyses were conducted using the SAEG software (UFV 2007).

\section{RESULTS AND DISCUSSION}

There was no significant effect $(p>0.05)$ for the interaction between plant density and mulch decomposition times for any of the analyzed variables. However, significant effects were largely observed for decomposition times and plant densities $(\mathrm{p}<0.05)$, with primary macronutrient concentrations displaying a significant effect $(\mathrm{p}>0.05)$ only for decomposition times.

The mean dry mass at the first cutting for the populations of $1,2,3$ and 4 plants $\mathrm{m}^{-2}$ were $5,457.8$;

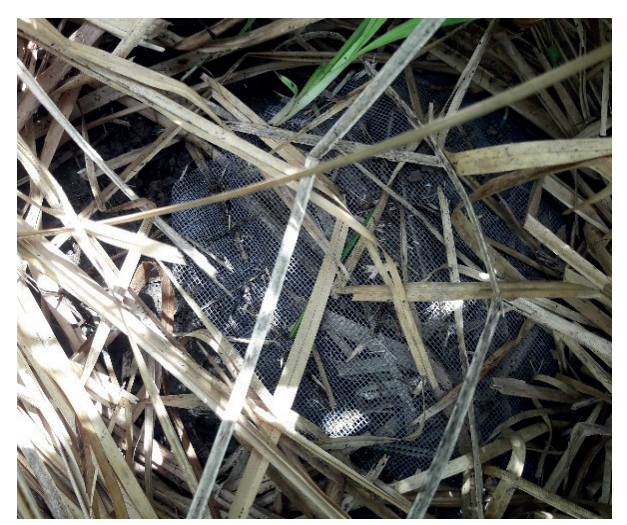

Figure 2. Positioning of the litter bags in the field. 
5,848.1; 5,512.6; and 4,174.4 $\mathrm{kg} \mathrm{ha}^{-1}$, respectively, with N, P and K contents of 32.9, 15.9 and $90.6 \mathrm{~kg} \mathrm{ha}^{-1}$, respectively, with no effect for plant density. This is because smaller plant densities exhibited larger grass clumps and vice versa, resulting in a similar biomass production between these treatments.

In general, considering all the assessed plant densities, the highest mulch dry mass values were recorded immediately after cutting. The decomposition was more intense at the first 15 days, when $663 \mathrm{~kg} \mathrm{ha}^{-1}$ of dry matter decomposed, decreasing to approximately $190 \mathrm{~kg} \mathrm{ha}^{-1}$ every 15 days up to 125 days (Figure $3 \mathrm{~A}$ ). Thus, about $2.05 \mathrm{Mg} \mathrm{ha}^{-1}$ of vetiver mulch dry matter decomposed over the 125-day period, with $3.25 \mathrm{Mg} \mathrm{ha}^{-1}$ remaining on the soil.

In regard to the $\mathrm{N}$ content of the vetiver mulch, the leaves contained an average of $6.5 \mathrm{~g} \mathrm{~kg}^{-1}$ shortly after cutting, which declined slightly up to 33 days and then increased up to 125 days, with the final
$\mathrm{N}$ content being 1.3 times higher than that initially measured (Figure 3).

On average, the highest $P$ and $K$ concentrations in the vetiver mulch dry matter were obtained immediately after cutting. As such, in the final sampling period, the mulch contained approximately 56 and $35 \%$ more $\mathrm{P}$ and $\mathrm{K}$, respectively, than the initial contents measured (Figure 3).

In general, the $\mathrm{N}$ content per hectare of vetiver mulch was higher shortly after cutting, with the lowest concentration obtained at 65 days, followed by a slight increase up to 125 days. Thus, at 65 and 125 days after cutting, the mulch had retained 73 and $76 \%$ of the $\mathrm{N}$ it contained directly after cutting, respectively (Figure 4). By contrast, the total amount of $\mathrm{N}$ released by the vetiver mulch was higher in the first few days after cutting, reaching a total of $5 \mathrm{~kg} \mathrm{ha}^{-1}$ up to day five $\left(1 \mathrm{~kg} \mathrm{ha}^{-1} \mathrm{day}^{-1}\right)$. The $\mathrm{N}$ release subsequently slowed to an average of $130 \mathrm{~g} \mathrm{ha}^{-1} \mathrm{day}^{-1}$ up to 40 days, and then decreased to approximately
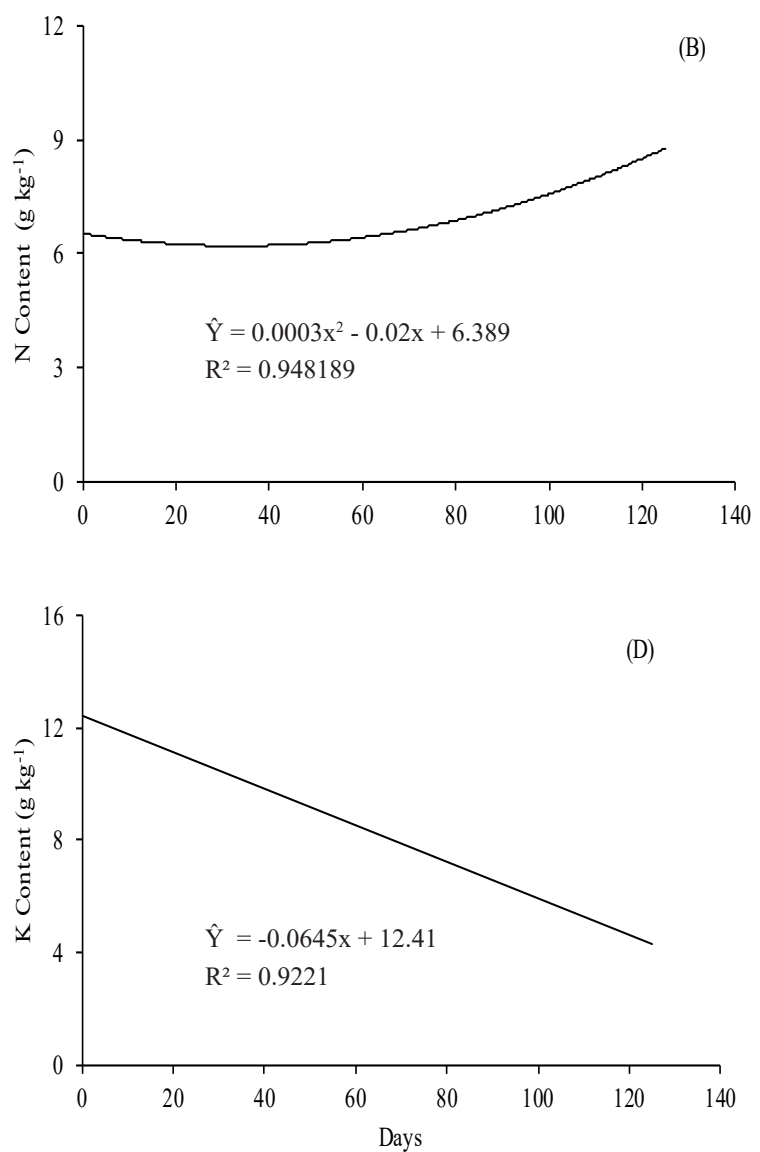

Figure 3. Average dry weight (A) and nitrogen (B), phosphorus (C) and potassium (D) contents in vetiver grass mulch grown at plant densities of $1,2,3$ and 4 plants $\mathrm{m}^{-2}$, considering the decomposition time. 
$18 \mathrm{~g} \mathrm{ha}^{-1}$ day $^{-1}$ until 65 days, reaching a total of $10 \mathrm{~kg} \mathrm{ha}^{-1}$. Between 65 and 125 days after cutting, the $\mathrm{N}$ content in the vetiver mulch increased by about $1.42 \mathrm{~kg} \mathrm{ha}^{-1}$ (Figure 4).

The $\mathrm{P}$ content was higher shortly after cutting and decreased linearly up to 125 days, when it corresponded to $37 \%$ of the initial value (Figure 4 ). Concomitantly, the amount of $\mathrm{P}$ released by the vetiver mulch was greater immediately after cutting, reaching a total of about $1.0 \mathrm{~kg} \mathrm{ha}^{-1}$ up to day five (200 $\mathrm{g} \mathrm{ha}^{-1}$ day $^{-1}$ ) and decreasing thereafter to an average of $69 \mathrm{~g} \mathrm{ha}^{-1}$ day $^{-1}$ up to 125 days after cutting, with a total of $9.4 \mathrm{~kg} \mathrm{ha}^{-1}$ of released P (Figure 4).

The highest average for $\mathrm{K}$ content was obtained shortly after cutting and then decreased to $25 \%$ of the initial value at 125 days (Figure 4 ).
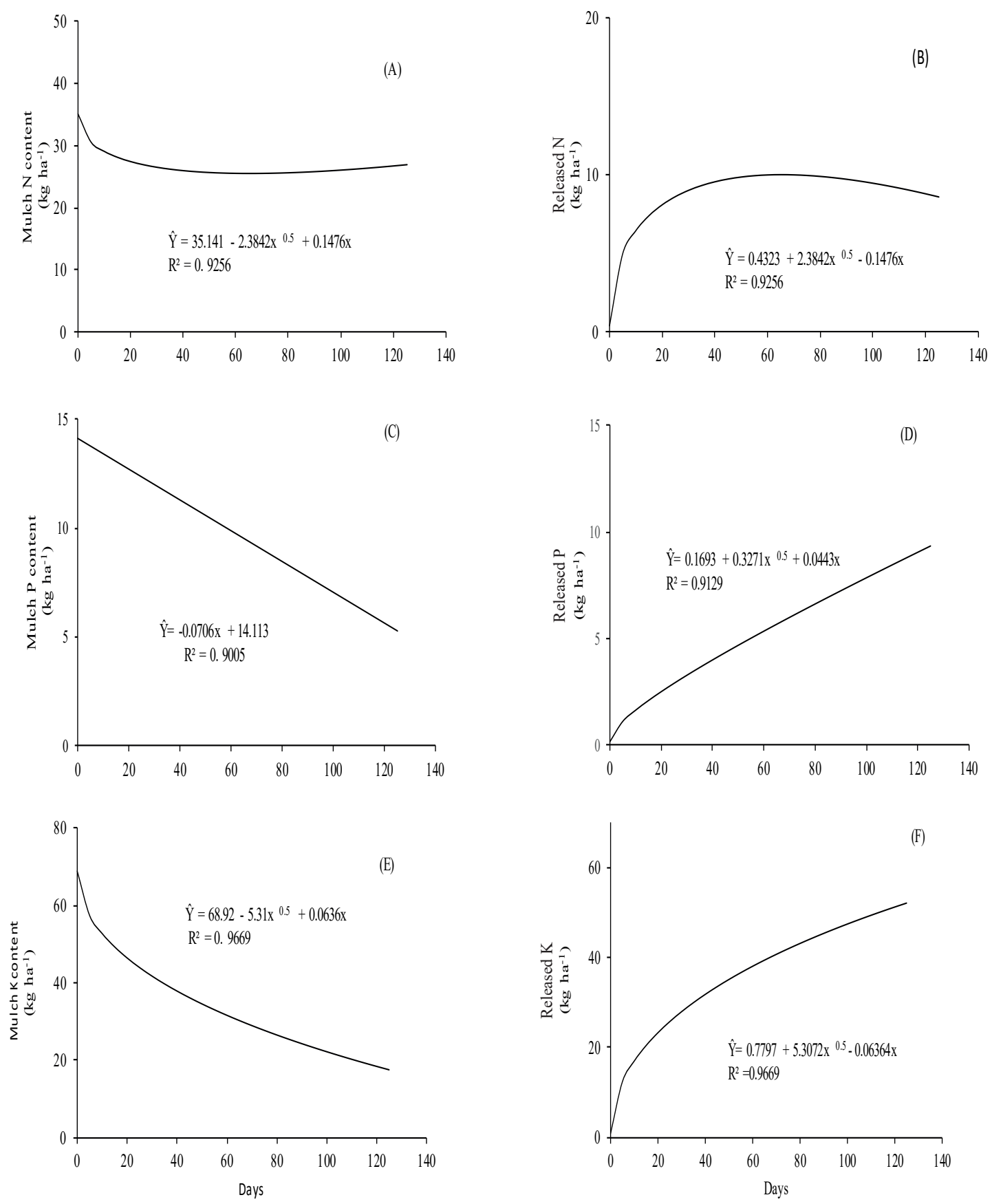

Figure 4. Contents of nitrogen (A), phosphorus (C) and potassium (E) and released amounts of N (B), P (D) and K (F) for plant densities of $1,2,3$ and 4 plants $\mathrm{m}^{-2}$, considering the decomposition time, in vetiver grass mulch. 
On the other hand, a substantial amount of $\mathrm{K}$ was released in the first five days after cutting $(11.5 \mathrm{~kg})$, at a rate of $2.3 \mathrm{~kg} \mathrm{ha}^{-1} \mathrm{day}^{-1}$, decreasing thereafter to an average of $333 \mathrm{~g} \mathrm{ha}^{-1}$ day $^{-1}$ up to 125 days, for a total of $51.4 \mathrm{~kg} \mathrm{ha}^{-1}$ of released P (Figure 4).

Plant density exhibited a significant effect on the mulch dry matter that remained on the soil over the 125-day period $(\mathrm{p}<0.05)$ (Figure 5), with the lowest amount of mulch cover obtained for the smallest population ( 1 plant $\mathrm{m}^{-2}$ ). Over the same time period, a density of 3 vetiver plants $\mathrm{m}^{-2}$ produced the highest dry matter, whereas intermediate amounts were observed for 2 and 4 plants $\mathrm{m}^{-2}$.

The plant density had no significant effect on the mulch $\mathrm{N}, \mathrm{P}$ and $\mathrm{K}$ contents $(\mathrm{p}<0.05)$ over the 125 days after cutting, with average values of 6.9 , 2.4 and $9.4 \mathrm{~g} \mathrm{~kg}^{-1}$, respectively.

The analyzed vetiver populations exhibited a significant effect on mulch $\mathrm{N}$ content $(\mathrm{p}<0.05)$
(Figure 5), with the lowest $\mathrm{N}$ content obtained at a density of 1 plant $\mathrm{m}^{-2}$, subsequently increasing to an estimated maximum at 3.3 plants $\mathrm{m}^{-2}$ and then decreasing up to 4 plants $\mathrm{m}^{-2}$. During the 125-day period assessed, the vetiver mulch contained an average of $11.4,3.5$ and $1.1 \mathrm{~kg} \mathrm{ha}^{-1}$ more $\mathrm{N}$ at a density of 3 plants $\mathrm{m}^{-2}$, when compared to populations of 1,2 and 4 plants $\mathrm{m}^{-2}$, respectively.

The analyzed vetiver populations exhibited a significant effect on mulch P content $(\mathrm{p}<0.05)$ (Figure 5), with mulch in the smallest population (1 plant $\mathrm{m}^{-2}$ ) containing the lowest $\mathrm{P}$ amount, peaking at estimated 2.9 plants $\mathrm{m}^{-2}$. At a density of 3 plants $\mathrm{m}^{-2}$, the mulch $\mathrm{P}$ contents were approximately $11.4,3.5$ and $1.1 \mathrm{~kg} \mathrm{ha}^{-1}$ higher than those obtained for populations of 1,2 and 4 plants $\mathrm{m}^{-2}$, respectively.

With respect to the $\mathrm{K}$ content, a significant effect was observed for the studied plant densities $(\mathrm{p}<0.05)$ (Figure 5), with the smallest population
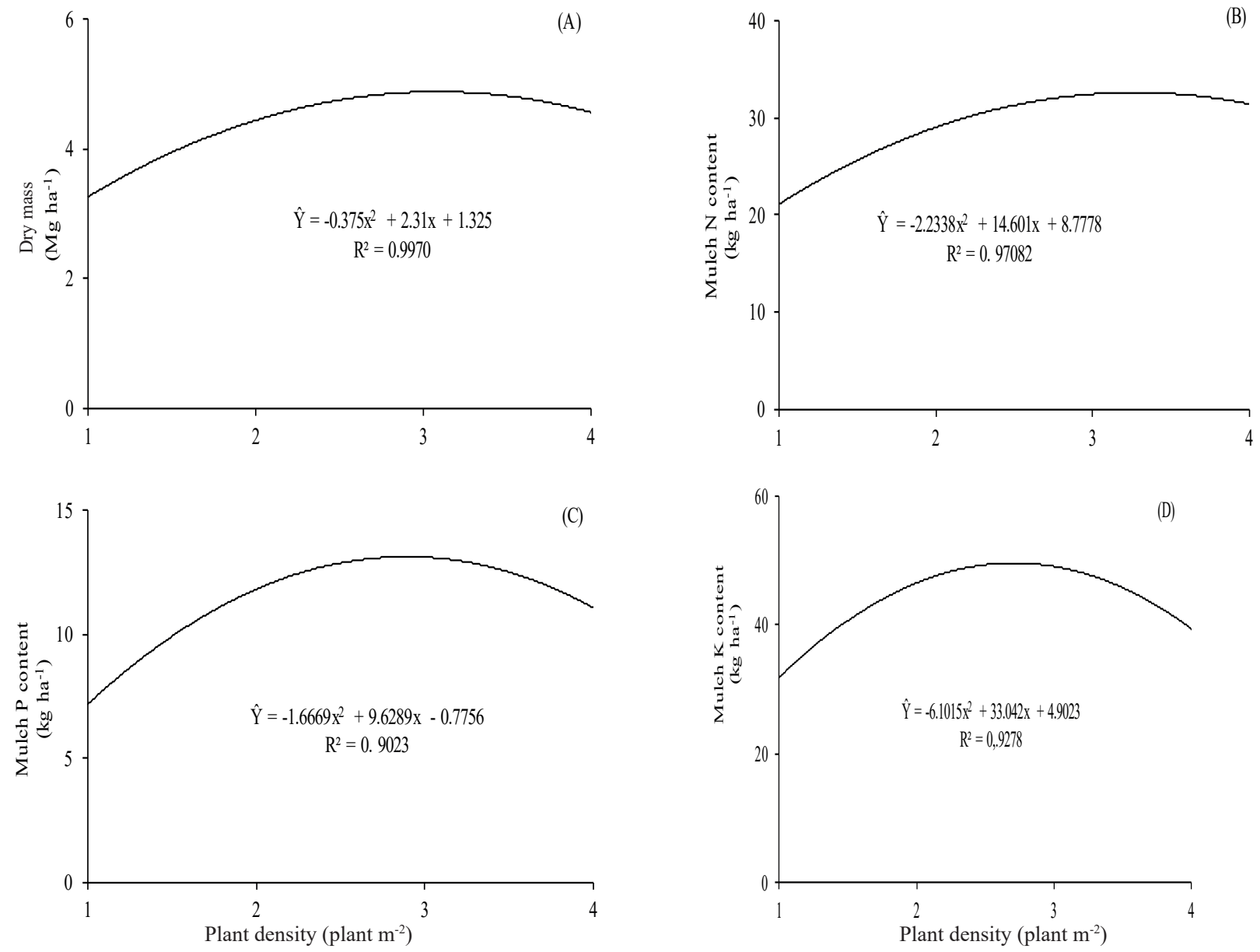

Figure 5. Average dry mass (A) and nitrogen (B), phosphorus (C) and potassium (D) contents for vetiver grass mulch over the 125-day period after cutting, considering the plant density. 
displaying the lowest concentrations, peaking at about 2.7 plants $\mathrm{m}^{-2}$. As such, the K contents at 125 days after cutting were approximately 17.3, 2.5 and $9.7 \mathrm{~kg} \mathrm{ha}^{-1}$ higher at 3 plants $\mathrm{m}^{-2}$ than at 1,2 and 4 plants $\mathrm{m}^{-2}$, respectively.

The analyzed plant densities showed no significant effect on the amount of $\mathrm{N}, \mathrm{P}$ and $\mathrm{K}$ released by the mulch $(p>0.05)$. Thus, considering the average values recorded for the different decomposition times, the vetiver mulch released approximately 7.2, 4.1 and $27.9 \mathrm{~kg} \mathrm{ha}^{-1}$ of $\mathrm{N}, \mathrm{P}$ and $\mathrm{K}$, respectively, for all the assessed populations.

The analysis of the mulch decomposition rate, at different plant densities, cut at 11 months after planting, indicated that the biomass produced by this grass species may be used as soil cover. In general, the vetiver mulch exhibited extended periods of coverage, and the fact that $2 / 5$ of the initial mulch decomposed in little more than 4 months is a good indicator for its application as soil cover. Although this is an important characteristic in plants used as soil cover, a slow decomposition rate is not favorable for green manure used in annual crops. Teixeira et al. (2012) found that $50 \%$ of pear millet and sorghum residues deposited on the soil took 105 and 75 days to decompose, respectively. Diniz et al. (2014) studied a green manure (Crotalaria juncea L.) and observed that, for doses of 9 and $6 \mathrm{Mg} \mathrm{ha}^{-1}$, the remaining dry mass of the residue took 53 and 44 days to decompose, respectively.

Torres et al. (2008) analyzed two decomposition times (before and after the annual crop cultivation) and found that $50 \%$ of the millet dry biomass took 131 days to decompose, followed by sorghum (117 days) and pigeon pea (113 days). For the second decomposition time, sunn hemp took 137 days to reach $50 \%$ of decomposition, followed by black oat and sorghum at 130 and 118 days, respectively.

According to Zhang et al. (2008), several factors are directly related to the decomposition rate, including latitude, ambient temperature, rainfall, chemical composition and nutrient content of litter, as well as a combination of characteristics that may accelerate decomposition.

The decomposition times studied here showed a significant effect on dry mass and mulch $\mathrm{N}, \mathrm{P}$ and $\mathrm{K}$ contents, accumulation of these macronutrients and the amount released into the soil.

The mulch dry mass decreased as the time after cutting increased (Figure 3 ); however, a higher
$\mathrm{N}$ content and $\mathrm{N}$ accumulation per hectare of mulch were recorded immediately after cutting, decreasing thereafter up to approximately 33 and 65 days, respectively, and then increasing to 125 days (Figures 3 and 4).

In the first few days following cutting, the mulch $\mathrm{N}$ content decreased (Figure 3 ) and more $\mathrm{N}$ was released into the soil (Figure 4), but the amount of $\mathrm{N}$ released during this period was below that expected for green manure. According to Balieiro et al. (2013), green manure can release 100 to $400 \mathrm{~kg} \mathrm{ha}^{-1}$ cycle $^{-1}$ of $\mathrm{N}$ through decomposition. In the present study, the increase in the $\mathrm{N}$ content and $\mathrm{N}$ accumulation in the mulch after 33 and 65 days, respectively (Figures 4 and 5), may be related to biological N fixation by diazotrophic bacteria (Siripin 2000) or electrical energy from lightening, which adds $\mathrm{N}$ to the soil or plant residue on its surface, during rainfall periods (Vieira 2017). Concomitantly, the increase in mulch $\mathrm{N}$ content near 125 days after cutting may also be associated with the fact that the concentration of more recalcitrant $\mathrm{N}$ substances (lignin) in the organic matter increases over time, due to the decline in more labile organic substances that decompose more quickly (Salmi et al. 2006). This causes an apparent $\mathrm{N}$ enrichment, which is actually the result of the reduced concentration of other substances due to decomposition.

On the other hand, the $\mathrm{P}$ and $\mathrm{K}$ contents, as well as the $\mathrm{P}$ and $\mathrm{K}$ accumulation in the mulch, declined over time (Figures 4 and 5).

Although the speed of $\mathrm{N}, \mathrm{P}$ and $\mathrm{K}$ release was higher in the first five days after cutting, the amounts released were small (5.0, 1.0 and $12 \mathrm{~kg} \mathrm{ha}^{-1}$, respectively). In general, the daily $\mathrm{N}, \mathrm{P}$ and $\mathrm{K}$ releases were lower from the fifth day onwards, with total values of 10.0, 9.4 and $51.4 \mathrm{~kg} \mathrm{ha}^{-1}$, respectively, up to 125 days after cutting and depositing the mulch on the soil. As such, the N, P and K released by the vetiver grass mulch could contribute to the nutrition of perennial plants, as opposed to short-cycle crops. This is because the amounts released are lower than those typically required by annual crops, and the release time involved exceeds the growth stages during which these nutrients are needed.

Gama-Rodrigues et al. (2007) observed a slow nutrient release rate in grasses, although $\mathrm{K}$ is released more quickly than $\mathrm{N}$ and $\mathrm{P}$.

For the assessed plant densities, 3 plants $\mathrm{m}^{-2}$ produced more mulch biomass per area and higher 
mulch N, P and K contents (Figure 5) over the 125day period after cutting.

\section{CONCLUSIONS}

1. Over the assessed 125 days, estimated $2.05 \mathrm{Mg} \mathrm{ha}^{-1}$ of vetiver mulch dry matter decomposed. However, the N, P and $\mathrm{K}$ releases were higher in the first few days after cutting;

2. The plant density of 3 plants $\mathrm{m}^{-2}$ exhibited the highest mulch dry mass at 125 days and contained more $\mathrm{N}, \mathrm{P}$ and $\mathrm{K}$, when compared to populations of 1,2 and 4 plants $\mathrm{m}^{-2}$.

\section{ACKNOWLEDGMENTS}

We would like to thank the Coordenação de Aperfeiçoamento de Pessoal de Nível Superior (Capes, MEC - Brazil - Finance Code 001), for financially supporting this research.

\section{REFERENCES}

ANTIOCHIA, R.; CAMPANELLA, L.; GHEZZI, P.; MOVASSAGHI, K. The use of vetiver for remediation of heavy metal soil contamination. Analytical and Bioanalytical Chemistry, v. 388, n. 4, p. 947-956, 2007.

ASSIS, R. L.; BOER, C. A.; PACHECO, L. P.; BRAZ, J. A. B. P.; COSTA, K. A. D. P.; TORRES, L. J. R. Produção e decomposição de biomassa de plantas de cobertura cultivadas na primavera. Energia na Agricultura, v. 31, n. 4, p. 328-333, 2016.

BALIEIRO, F. C.; BERBARA, R.; FARIA, S. M.; DEPOLLI, H.; FRANCO, A. A. Insumos biólogicos. In: FREIRE, L. R.; BALIEIRO, F. C.; ZONTA, E.; ANJOS, L. H. C.; PEREIRA, M. G.; LIMA, E.; GUERRA, J. G. M.; FERREIRA, M. B. C.; LEAL, M. A. A.; CAMPOS, D. V. B.; POLIDORO, J. C. (ed.). Manual de calagem e adubação do estado do Rio de Janeiro. Rio de Janeiro: Embrapa, 2013. p. 167-188.

BANERJEE, R.; GOSWAMI, P.; LAVANIA, S.; MUKHERJEE, A.; LAVANIA, U. C. Vetiver grass is a potential candidate for phytoremediation of iron ore mine spoil dumps. Ecological Engineering, v. 132, n. 7, p. 120-136, 2019.

BARROS JUNIOR, V. L. M. Utilização do radar de penetração em dois solos do norte fluminense. 2011. Dissertação (Mestrado em Produção Vegetal) Universidade Estadual do Norte Fluminense Darcy Ribeiro, Campos dos Goytacazes, 2011.
BRASIL. Instituto Nacional de Meteorologia. Estação meteorológica de observação de superfície automática. 2018. Disponível em: http://www.inmet.gov.br/portal/ index.php? $\mathrm{r}=$ estacoes/estacoesAutomaticas. Acesso em: 8 set. 2018.

CARVALHO, A. M. D.; SOUZA, L. L. P. D.; GUIMARÃES JÚNIOR, R.; ALVES, P. C. A. C.; VIVALDI, L. J. Cover plants with potential use for crop-livestock integrated systems in the Cerrado region. Pesquisa Agropecuária Brasileira, v. 46, n. 10, p. 12001205, 2011.

CRUSCIOL, C. A. C.; MORO, E.; LIMA, E. D. V.; ANDREOTTI, M. Taxas de decomposição e de liberação de macronutrientes da palhada de aveia preta em plantio direto. Bragantia, v. 67, n. 2, p. 481-489, 2008.

DANH, L. T.; TRUONG, P.; MAMMUCARI, R.; TRAN, T.; FOSTER, N. Vetiver grass, Vetiveria zizanioides: a choice plant for phytoremediation of heavy metals and organic wastes. International Journal of Phytoremediation, v. 11, n. 8, p. 664-691, 2009.

DINIZ, E. R.; VARGAS, T. O.; PEREIRA, W. D.; GUEDES, A. F.; SANTOS, R. H. S.; PETERNELLI, L.A. Decomposição e mineralização do nitrogênio proveniente do adubo verde Crotalaria juncea. Cientifica, v. 42, n. 1, p. 51-59, 2014.

D'SOUZA, D. N.; CHOUDHARY, A. K.; BASAK, P.; SHUKLA, S. K. Assessment of vetiver grass root reinforcement in strengthening the soil. Ground Improvement Techniques and Geosynthetics, v. 14, n. 1, p. 135-142, 2019.

GAMA-RODRIGUES, A. C. D.; GAMA-RODRIGUES, E. F. da; BRITO, E. C. D. Decomposição e liberação de nutrientes de resíduos culturais de plantas de cobertura em Argissolo Vermelho-Amarelo na região noroeste fluminense (RJ). Revista Brasileira de Ciência do Solo, v. 31, n. 6, p. 1421-1428, 2007.

GOŁĘBIEWSKI, M.; TARASEK, A.; SIKORA, M.; DEJA-SIKORA, E.; TRETYN, A.; NIKLIŃSKA, M. Rapid microbial community changes during initial stages of pine litter decomposition. Microbial Ecology, v. 77, n. 1, p. 56-75, 2019.

JACKSON, M. L. Soil chemical analysis. New Jersey: Prentice Hall, 1965.

KLIEMANN, H. J.; BRAZ, A. J. P. B.; SILVEIRA, P. M. D. Taxas de decomposição de resíduos de espécies de cobertura em Latossolo Vermelho Distroférrico. Pesquisa Agropecuária Tropical, v. 36, n. 1, p. 21-28, 2006.

LAKSHMI, C. S.; SEKHAR, C. C. Role of Vetiveria zizanioides in soil protection and carbon sequestration. The Pharma Innovation Journal, v. 9, n. 9, p. 492-494, 2020. 
LAL, R. K. On genetic diversity in germplasm of vetiver "Veteveria zizanioides (L.) Nash". Industrial Crops and Products, v. 43, n. 1, p. 93-98, 2013.

LINHARES, P. C. F.; SILVA, M. L.; SILVA, U. L.; SILVA, J. D. S.; BEZERRA, A. K. D. H. Velocidade e tempo de decomposição da jitirana incorporada na cultura do rabanete. Revista Caatinga, v. 22, n. 2, p. 213-217, 2009.

MASON, C. F. Ciclos biogeoquímicos: decomposição. São Paulo: Ed. Pedagógica e Universitária, 1980.

SALMI, G. P.; SALMI, A. P.; ABBOUD, A. C. S. Dinâmica de decomposição e liberação de nutrientes de genótipos de guandu sob cultivo em aleias. Pesquisa Agropecuária Brasileira, v. 41, n. 4, p. 673-678, 2006.

SIRIPIN, S. Microbiology associated with the vetiver plant. In: CHOMCHALOW, N.; BARANG M. (ed.). Proceedings of the second international conference on vetiver (ICV-2). Bangkok: Office of the Royal Development Projects Board, 2000. p. 374-376.

SHABBIR, A.; KHAN, M. M. A.; AHMAD, B.; SADIQ, Y.; JALEEL, H.; UDDIN, M. Vetiveria zizanioides (L.) Nash: a magic bullet to attenuate the prevailing health hazards. Plant and Human Health, v. 2, n. 1, p. 99-120, 2019.

TEIXEIRA, M. B.; LOSS, A.; PEREIRA, M. G.; PIMENTEL, C. Decomposição e ciclagem de nutrientes dos resíduos de quatro plantas de cobertura do solo. Idesia (Arica), v. 30, n. 1, p. 55-64, 2012.

THOMAS, R. J.; ASAKAWA, N. M. Decomposition of leaf litter from tropical forage grasses and legumes. Soil Biology and Biochemistry, v. 25, n. 10, p. 1351-1361, 1993.

TORRES, J. L. R.; PEREIRA, M. G.; FABIAN, A. J. Produção de fitomassa por plantas de cobertura e mineralização de seus resíduos em plantio direto. Pesquisa Agropecuária Brasileira, v. 43, n. 3, p. 421-428, 2008.

UNIVERSIDADE FEDERAL DE VIÇOSA(UFV). SAEG: sistema para análises estatísticas e genéticas. Versão 9.1. Viçosa: Fundação Arthur Bernardes, 2007. 1 CD-ROM.

VIEIRA, R. F. Ciclo do nitrogênio em sistemas agrícolas. Brasília, DF: Embrapa, 2017.

ZHANG, D.; HUI, D.; LUO, Y.; ZHOU, G. Rates of litter decomposition in terrestrial ecosystems: global patterns and controlling factors. Journal of Plant Ecology, v. 1, n. 2, p. 85-93, 2008. 